\title{
REGULATION CONCERNING SEAFARER ON MARITIME LABOR CONVENTION 2006
}

Thio Haikal Anugerah

Universitas Lampung, Indonesia, Email: thio.haika197@gmail.com

Submitted: September 23, 2019; Reviewed: October 14, 2019; Accepted: Actober 31, 2019

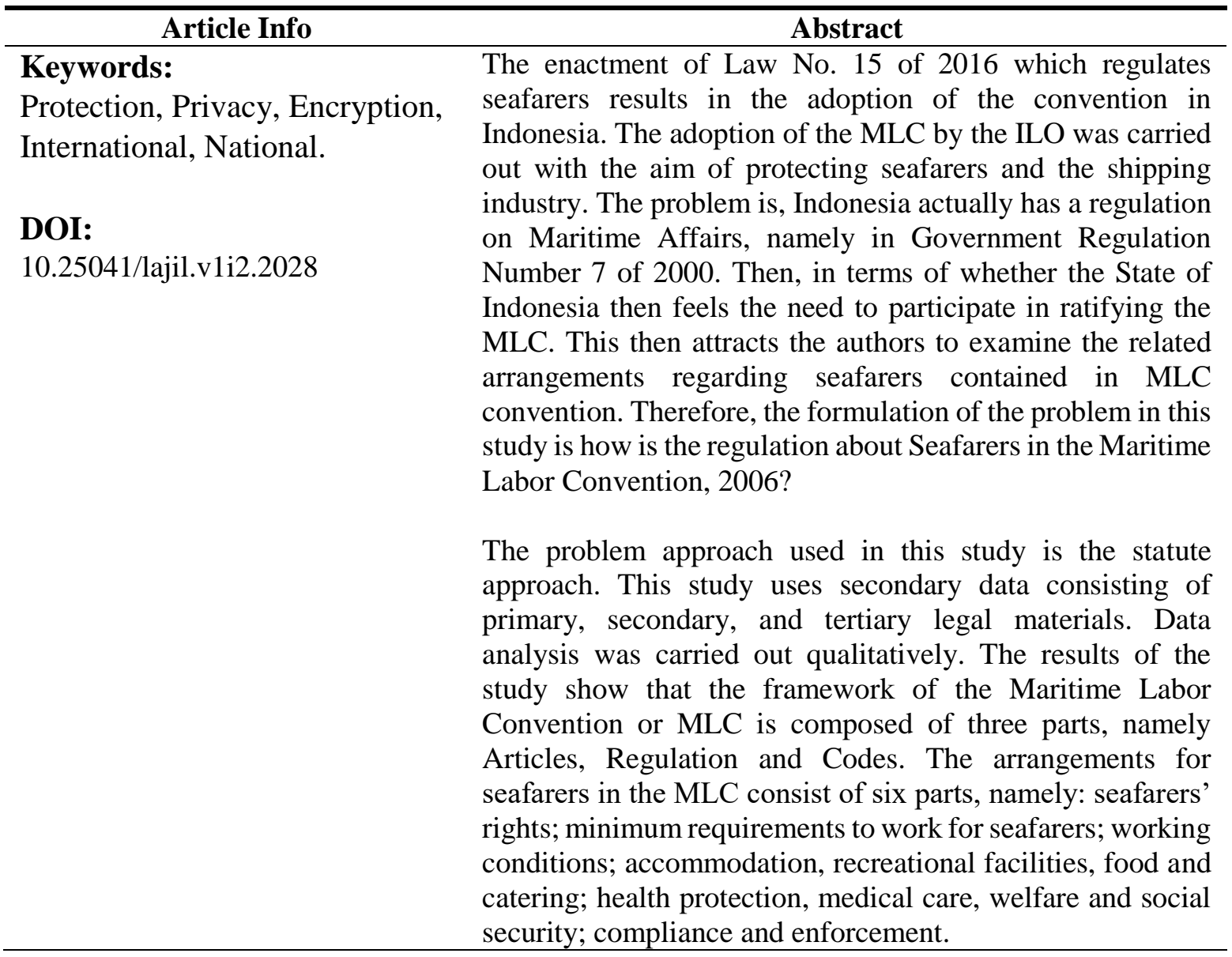

\section{A. Introduction}

The Unitary State of the Republic of Indonesia is an archipelagic state characterized by an archipelago that is united by vast territorial waters with boundaries, rights, and sovereignty stipulated by law. ${ }^{1}$ As an archipelagic state with $17,499^{2}$ islands stretching from Sabang to Merauke, and a total area of 7.81 million $\mathrm{km} 2$ in which two-thirds is oceanic, it is a great opportunity for Indonesians to use the sea as a source of livelihood.

The sea promises the enormous commercial potential for the Indonesian people. However, this potential will not be meaningful if there are no human resources as those who utilize marine potential.

\footnotetext{
${ }^{1}$ Consideration Part of Law No. 17 Year 2008 concerning Shipping.

2 https://kkp.go.id/artikel/2233-maritim-indonesia-kemewahan-yang-luar-biasa, Accessed on September 10, 2018.
} 
Some of the potentials of the oceans in Indonesia include ${ }^{3}$ Fish resources, plants in the sea, mineral resources and mining, transportation, recreational facilities or marine tourism.

One type of work that people can do by in the ocean is a seafarer. Seafarers in Government Regulation No. 7 of 2000 concerning Maritime Affairs (hereinafter referred to as PP No.7 of 2000) is defined as any person who has a qualification or expertise or skill as a crew, ${ }^{4}$ the crew itself is defined as a person who works or is employed on board by a shipowner or operator to do assignments on board according to the position stated in the national seafarer's book. ${ }^{5}$

In 2016, the Indonesian government promulgated Law Number 15 of 2016 concerning Ratification of the Maritime Labor Convention, 2006. The Maritime Labor Convention or MLC is the Maritime Employment Convention adopted at the 94th International Labor Conference, February 23, 2006, in Geneva, Switzerland. This convention focuses on the efforts of member countries of the International Labor Organization or the ILO to protect seafarers and the shipping industry.

Since adopted by the ILO in 2006 to be ratified by Indonesia in 2016, there has been a span of around 10 years between 2006 and 2016 which raises the question why the Indonesian government did not immediately ratify this MLC. Based on the research conducted by Salmah Wati, this was due to at least three problems, namely: ${ }^{6}$ First, a conflict of interest between the Ministry of Manpower and Transmigration and the Ministry of Transportation. Second, the unpreparedness of the Government and the Indonesian National Ship Company (INSA) to fulfil the provisions of the MLC. Third, the government's concern will be the emergence of a domino effect that can hinder the rate of growth in the economic sector.

As explained earlier, the adoption of the MLC by the ILO was carried out to provide protection for seafarers and the shipping industry. The problem is, Indonesia actually has a regulation on Maritime Affairs, namely in Government Regulation Number 7 of 2000 concerning Maritime Affairs. Then, in terms of whether the State of Indonesia then feels the need to participate in ratifying the MLC. This then attracts the authors to examine the related arrangements regarding seafarers contained in MLC convention. Therefore, the problem formulation in this study is how is the regulation about Seafarers in the Maritime Labor Convention, 2006? This research is classified into a type of normative legal research ${ }^{7}$ who studies the product of legislation (legal approach) ${ }^{8}$ by examining library materials or secondary data and analyzing the data carried out qualitatively. In this study, researchers used a statute approach.

\section{B. Discussion}

\section{The Concepts of Seafarer}

The term "seafarer" can be defined as "shipboard crew personnel involving Ships' Officers and seamen/ratings". ${ }^{9}$ In this study, the scope of a seafarer has a lot of meaning but limited in the context of the seafarer as work formed through working relationships. This means seafarer who are the subjects of this study are seafarer who is bound to civil employment relationships with those who employ them. So, another seafarer who do sailing work but on their own initiative, without working relations, does not include in the meaning of seafarers in this study.

The definition of a seafarer in this research refers to Government Regulation Number 7 of 2000 concerning Maritime Affairs and MLC. In the PP No.7 of 2000, seafarer means as anyone who has the qualifications or skills as a crew. Whereas the crew, still in the same rules, are defined as people

\footnotetext{
${ }^{3}$ Sukamto "PENGELOLAAN POTENSI LAUT INDONESIA DALAM SPIRIT EKONOMI ISLAM," Jurnal Ekonomi Islam 9, no. 1 (2017): 35-62, 36, DOI: 10.35891/ml.v9i1.881.

${ }^{4}$ Article 1 Sub article 3 Government Regulation No. 7 Year 2000 concerning Maritime Affair

${ }^{5}$ Article 1 Sub article 2 Government Regulation No. 7 Year 2007.

${ }^{6}$ Salmah Wati "KEPENTINGAN INDONESIA TIDAK MERATIFIKASI MARITIME LABOR CONVENTION (MLC) TAHUN 2006-2014,” Jom FISIP 1, no. 2 (2014): 1-14, 13.

${ }^{7}$ Soerjono Soekanto, Penelitian Hukum Normatif Suatu Tinjauan Singkat (Jakarta: Rajawali Pers, 2013) 1

8 Defi Fitri et al., "ASPEK HUKUM PERENCANAAN, PENGADAAN DAN PENEMPATAN SUMBER DAYA MANUSIA KESEHATAN DI PUSKESMAS KOTA METRO LEGAL ASPECTS OF PLANNING, PROVISION AND PLACEMENT OF HUMAN RESOURCES IN SOCIETY HEALTHY CENTRE (PUSKESMAS) OF METRO CITY," Cepalo 1, no. 1 (2019): 31-40, 32, DOI: 10.25041/cepalo.v1no1.1753.

${ }^{9}$ A.E. Branch, D. Branch (eds), Dictionary of shipping. International business trade terms and abbreviations (London: Witherby, 2005) 301.
} 
who work or are employed on board by the owner or operator of the ship to carry out duties on the ship according to the position listed in the national seafarer's book, ${ }^{10}$ while on MLC, Seafarer means any person who is employed or engaged or works in any capacity onboard a ship to which this convention applies.

Although the definitions of "seafarer" under different existing labour conventions are slightly different, the main criterion for a person to be considered as a seafarer is their work onboard a ship to which the convention applies. Additionally, sometimes other criteria are mentioned (e.g., work in the deck department, entered in the ship's articles). The content of many ILO conventions primarily speaks to the employment situation of personnel involved in some way in the operation of the ship the "crew". 11

\section{Raison d'etre Maritime Labor Convention}

Viewed from the MLC preamble, the reason of being of this convention is intended to create a single instrument that is interrelated and wherever possible contains all the latest standards of applicable maritime labour international conventions and recommendations as well as the basic principles contained in other labor conventions. Other considerations for the establishment of the MLC are also due to the global nature of the shipping industry. Therefore seafarers need special protection and also pay attention to international standards regarding ship safety, humanitarian, social security and quality of shipping management, as well as training for seafarer and competence and certification. In addition, the ILO constitution which stipulates that the adoption of a convention or recommendation by a congregation or ratification by member states ensures more favourable conditions for workers. ${ }^{12}$

According to Maunikum Veganaden, ${ }^{13}$ MLC is a representation presented by the ILO to be a solution to various shortcomings or loopholes and grey areas in order to improve welfare, education, and social conditions for seafarers who are the main actors in the shipping industry. The adoption of this convention is intentionally intended to be applied globally, because it is easy to understand, ready for whenever to be updated and fully implemented.

\section{The Framework of the Maritime Labor Convention}

The Maritime Labour Convention, 2006 (MLC), otherwise known as the Seafarers' Bill of Rights, incorporates and builds on sixty-eight existing maritime labour conventions and recommendations, as well as more general fundamental principles, to ensure decent working and living conditions for all seafarers. ${ }^{14}$ The MLC was developed as a result of a trinity consultation by the delegates of government, employers and worker organizations. The convention aims to provide detailed rights and safeguards for seafarers and to succeed in occupational health and safety protection and prevention arrangements in their working and living areas. ${ }^{15}$

This convention consists of three parts. First, articles, second is regulations, and third is codes. Articles and regulations stipulate the main rights and principles and basic obligations of member countries that ratify the convention. Amendments to the articles and regulations can only be changed by the session according to the framework as set out in the ILO constitution. ${ }^{16}$ Codes contain details of the application of regulations. The codes consist of Part A, which must be implemented, and Part $\mathrm{B}$, which is optional to be implemented. Amendments to the codes can be made through the procedure as stipulated in Article XV MLC.

\footnotetext{
${ }^{10}$ Article 1 number 2 and 3 Government Regulation No. 7 Year 2000.

${ }^{11}$ Sandra Lielbarde, "CONCEPT OF SEAFARER BEFORE AND AFTER THE MARITIME LABOUR CONVENTION 2016: COMPARATIVE ANALYSIS OF THE LEGAL EFFECTS OF DEFINING LEGAL CONCEPTS IN THE SHAPE OF LEGAL TERMINOLOGY," RGSL Research Paper 17 (2017): 1-24, 5.

${ }^{12}$ Preamble of MLC, 2006.

${ }^{13}$ Maunikum Veganaden, The Potential Implications of the Maritime Labor Convention, 2006, for Policy and Management in the Maritime Sector: A Critical Analysis (Sweden: World Maritime University, 2007) 3.

${ }_{14}$ The International Transport Workers' Federation (ITF), An ITF Guide for Seafarers to the ILO Maritime Labour Convention (London: The International Transport Workers' Federation (ITF), 2006) 1.

${ }^{15}$ Şevket Süleyman İRTEM, Sibel BAYAR, Güler ALKANP "THE IMPLEMENTATION OF MARITIME LABOUR CONVENTION IN THE SHIP MANAGEMENT: A CASE STUDY ON RISK MANAGEMENT ON-BOARD," International Journal of Operations and Logistics Management 4, no. 4 (2015): 253-267, 254.

${ }^{16}$ Article XIV MLC, 2006.
} 
Articles in the MLC consist of 16 Articles, with details as follows:

a. Article I: General Obligations;

b. Article II: Definitions and Scope of Application;

c. Article III: Fundamental Rights and Principles;

d. Article IV: Seafarer's Employment and Social Rights;

e. Article V: Implementation and Enforcement Responsibilities;

f. Article VI: Regulations and Parts A and Parts B of The Code;

g. Article VII: Consultations with Shipowners' and Seafarers' Organization;

h. Article VIII: Entry into Force;

i. Article IX: Denunciation;

j. Article X: Effect of Entry into Force;

k. Article XI dan XII: Depository Functions;

1. Article XIII: Special Tripartite Committee;

m. Article XIV: Amendment of This Convention;

n. Article XV: Amendment To The Code;

o. Article XVI: Authoritative Languages.

Article I MLC is the General Obligations, containing the obligation of the parties to ratify the MLC to fully implement the MLC and cooperate in implementing and enforcing the MLC effectively.

Article II MLC, berisi pengertian-pengertian yang digunakan dalam konvensi, seperti competent authority, gross tonage, etc. selain pengertian, Article ini juga memuat scope of application dari MLC.

Article II MLC, contains the definitions used in the convention, such as competent authority, gross tonnage, etc. this Article also contains the scope of application from MLC.

Article III MLC contains fundamental rights and principles contained in the MLC, namely freedom of association and the effective recognition of the right to collective bargaining, the elimination of all forms of forced or compulsory labour, the effective abolition of child labour, the elimination of discrimination in respect of employment and occupation.

Article IV MLC contains seafarer's employment and social rights, namely: Every seafarer has the right to a safe and secure workplace that complies with safety standards, every seafarer has the right to fair terms of employment, every seafarer has a right to decent working and living conditions on board ship and every seafarer has a right to health protection, medical care, welfare measures, and other forms of social protection.

Article $\mathrm{V}$ contains the obligation for member countries to implement all provisions of the convention and be responsible for ensuring that no ship is treated specifically according to this convention.

Article VI contains an explanation of regulations and codes. Regulations contain general standards, while codes consist of two parts, code A and code B. Regulations and Code A are mandatory, while Code B is facultative or not mandatory.

Article VII contains the obligation to consult with the shipowners' and seafarers' organizations in the event of derogation, exemption or other flexible application of this convention for which the convention requires consultation.

Article VIII contains conditions when MLC can apply. For example, this convention is said to be valid if it has ratified 30 member countries with a total share of 33 per cent of the gross tonnage of ships in the world.

Article IX contains denunciation; a member who has ratified this convention may denounce it after the expiration of ten years from the date on which the convention first comes into force, by an act communicated to the Director-General of the International Labor Office for registration. Each member who does not, within the year following the expiration of the period of ten years mentioned above, exercise the right of denunciation provided for in this article, shall be bound for another period of ten years and, thereafter, may denounce this convention at the expiration of each new period of ten years under the terms provided for.

Article X contains the effect of applying the MLC where the implementation of this MLC convention, then each member country has revised some conventions, which are contained in this article. 
Article XI and Article XII contain the depository functions in which all ratifications, acceptances and denunciations under this convention must be notified and registered according to the provisions of this article.

Article XIII contains the establishment of a special tripartite committee whose duty is to safeguard and review the application of MLC provisions.

Article XIV contains the mechanisms and procedures that must be taken for each party who wishes to amend the MLC.

Article XV contains the mechanisms and procedures that must be taken to amend the codes.

Article XVI contains the official language used in this convention, namely English and French.

Regulation and Codes are generally grouped into five section titles, namely: Minimum requirements for seafarers to work on a ship; conditions of employment; accomodation, recreational facilities, food and catering; health protection, medical care, welfare and social security protection; compliance and enforcement.

\section{The Regulation concerning Seafarer on Maritime Labor Convention, 2006}

Regulations concerning seafarer on MLC are generally grouped into six section titles, namely: Seafarer's right; minimum requirements for seafarers to work on a ship; conditions of employment; accommodation, recreational facilities, food and catering; health protection, medical care, welfare and social security protection; compliance and enforcement.

Seafarer's rights on MLC are divided into two types. The first form is fundamental rights, meaning that must be respected, guaranteed and fulfilled by every party involved in the scope of the convention, which includes:

a. Freedom of association and the effective recognition of the right to collective bargaining;

b. The elimination of all forms of forced or compulsory labour;

c. The effective abolition of child labour; and

d. The elimination of discrimination in respect of employment and occupation.

The second type is seafarer's social rights and their rights as a worker, which consists of: ${ }^{17}$

a. Every seafarer has the right to a safe and secure workplace that complies with safety standards;

b. Every seafarer has the right to fair terms of employment;

c. Every seafarer has a right to decent working and living conditions on board ship;

d. Every seafarer has a right to health protection, medical care, welfare measures, and other forms of social protection.

Regarding the requirements for seafarer to work on ships. Four minimum aspects must be met by seafarers who want to work on a ship in MLC. First, regarding the minimum age allowed to work as a seafarer. Second, regarding medical certificates that must be owned by seafarers as proof that he is physically fit to work on a ship. Third, training and qualifications regarding the competency of the seafarer. And finally, the recruitment and placement of seafarer themselves. ${ }^{18}$

In the part of the conditions of work regulated on MLC, there are at least eight aspects which are the focus, that is: seafarers' employment agreements; wages; hours of work and hours of rest; entitlement to leave; repatriation; seafarer compensation for the ship's loss or foundering; manning levels; career and skills development and opportunities for seafarers' employment.

Accommodation, recreational facilities, food and catering, are the third aspects that are integrally regulated in the rules and rules of MLC. To ensure seafarers have adequate accommodation and recreational facilities onboard, each member country must ensure that the country's flagged ships provide adequate accommodation and recreational facilities for seafarers on board. ${ }^{19}$ Regarding the description of the accommodation and what facilities should be provided to seafarers are regulated at the Codes.

Regarding medical care on ships and on land, in order to protect the health of seafarers and ensure rapid access, each member country must ensure that all seafarers on the ship with the flag of their country are protected by appropriate policies to protect their health. Therefore member countries

\footnotetext{
${ }^{17}$ Article IV, MLC 2006.

${ }^{18}$ Title 1, Regulation and Codes, MLC.

${ }^{19}$ Regulation 3.1. MLC.
} 
need to ensure that there is access to prompt and adequate medical care when seafarers work on ships. Protection and care in principle is an obligation and access to it must be free of charge.

In the last section, namely compliance and enforcement, it is stipulated that each members of MLC is responsible for fully implementing and enforcing the principles and rights set out in the Articles of MLC and special obligations regarding: Minimum requirements for seafarers to work on a ship; conditions of employment; accommodation, recreational facilities, food and catering; health protection, medical care, welfare and social security protection

\section{Conclusion}

Seafarer refers to Government Regulation Number 7 of 2000 concerning Maritime Affairs is anyone who has the qualifications or skills as a crew. Whereas the crew, still in the same rules, are defined as people who work or are employed on board by the owner or operator of the ship to carry out duties on the ship according to the position listed in the national seafarer's book. MLC define seafarer is any person who is employed or engaged or works in any capacity on board a ship to which this convention applies.

The framework of the Maritime Labor Convention or MLC is composed of three parts, namely Articles, Regulation and Codes. The arrangements for seafarers in the MLC consist of six parts, namely: seafarers' rights; minimum requirements to work for seafarers; working conditions; accommodation, recreational facilities, food and catering; health protection, medical care, welfare and social security; compliance and enforcement.

\section{A. Journal}

\section{References}

Fitri, Defi et al., "ASPEK HUKUM PERENCANAAN, PENGADAAN DAN PENEMPATAN SUMBER DAYA MANUSIA KESEHATAN DI PUSKESMAS KOTA METRO LEGAL ASPECTS OF PLANNING, PROVISION AND PLACEMENT OF HUMAN RESOURCES IN SOCIETY HEALTHY CENTRE (PUSKESMAS) OF METRO CITY," Cepalo 1, no. 1, 2019: 31-40, DOI: 10.25041/cepalo.v1no1.1753.

Lielbarde, Sandra. "CONCEPT OF SEAFARER BEFORE AND AFTER THE MARITIME LABOUR CONVENTION 2016: COMPARATIVE ANALYSIS OF THE LEGAL EFFECTS OF DEFINING LEGAL CONCEPTS IN THE SHAPE OF LEGAL TERMINOLOGY.” $R G S L$ Research Paper 17, 2017: 1-24.

Salmah, Wati "KEPENTINGAN INDONESIA TIDAK MERATIFIKASI MARITIME LABOR CONVENTION (MLC) TAHUN 2006-2014.” Jom FISIP 1, no. 2, 2014: 1-14.

Şevket Süleyman İRTEM, Sibel BAYAR, Güler ALKANP. "THE IMPLEMENTATION OF MARITIME LABOUR CONVENTION IN THE SHIP MANAGEMENT: A CASE STUDY ON RISK MANAGEMENT ON-BOARD." International Journal of Operations and Logistics Management 4, no. 4, 2015: 253-267.

Sukamto. "PENGELOLAAN POTENSI LAUT INDONESIA DALAM SPIRIT EKONOMI ISLAM.” Jurnal Ekonomi Islam 9, no. 1, 2017: 35-62, DOI: 10.35891/ml.v9i1.881.

\section{B. Book}

Branch, A. E. Dictionary of shipping. International business trade terms and abbreviations. London: Witherby, 2005.

Maunikum, Veganaden. The Potential Implications of the Maritime Labor Convention, 2006, for Policy and Management in the Maritime Sector: A Critical Analysis. Sweden: World Maritime University, 2007.

Soerjono, Soekanto. Penelitian Hukum Normatif Suatu Tinjauan Singkat. Jakarta: Rajawali Pers, 2013.

The International Transport Workers' Federation (ITF). An ITF Guide for Seafarers to the ILO Maritime Labour Convention. London: The International Transport Workers' Federation (ITF), 2006.

\section{Regulation}

Government Regulation No. 7 Year 2000 concerning Maritime Affair 
Law No. 17 Year 2008 concerning Shipping.

Maritime Labor Convention, 2006

D. Internet

https://kkp.go.id/artikel/2233-maritim-indonesia-kemewahan-yang-luar-biasa,

Accessed

on

September 10, 2018. 
